\title{
Chinese Jews and China-Israel Relation
}

\author{
Song Jian ${ }^{1,2}$ \\ ${ }^{1}$ Chinese Academy of Engineering, Beijing, China \\ ${ }^{2}$ Chinese Academy of Science, Beijing, China \\ Email: songj@cae.cn
}

Received 1 August 2014; revised 4 September 2014; accepted 26 September 2014

Academic Editor: Shaodan Luo, Wuhan Irvine Culture and Communications, China

Copyright (C) 2014 by author and Scientific Research Publishing Inc.

This work is licensed under the Creative Commons Attribution International License (CC BY).

http://creativecommons.org/licenses/by/4.0/

(c) (i) Open Access

\section{Abstract}

This is a passage excerpted from its author's memoir written recently. The author recounts the role he played in the establishment of official diplomatic relation between the People's Republic of China and Israel 20 years ago. The memoir cites the historical records that show a considerable Jewish community who migrated from Mumbai, India 1000 years ago and settled down in Kaifeng, the Capital of Song Dynasty (960-1127). The ensuing emperors, personally concerned about these Diasporas, allowed them to stay in the Capital, conferred Chinese surnames upon them, and made official positions in government obtainable by them. Synagogues had stood in Kaifeng for as long as 700 years until they were finally destroyed by a big flood in 1854 . Since then they had never been restored. The Jewish community gradually dispersed nationwide and fully intermixed with other ethnicities via intermarriage. Now millions of Chinese people may have distant lineage from Kaifeng Jews. China is one of a few countries that have always been treating Diasporas graciously as compatriots for a millennium.

\section{Keywords}

Diplomatic Relation, Science-Technology Cooperation, People's Republic of China, Israel, Chinese Jews, Distant Lineage

In 1956, my senior year at Moscow Bauman State Technical University (MBTU), we began studying professional courses in the control of artillery. Our main field was automatic control of antiaircraft artillery. A gunlaying radar can automatically track hostile planes, detect target positions, distances and flight speeds, calculate the direction and ballistic trajectory of projectiles and preset detonating time of fuses to trigger explosions nearest to the target. At that time, there were no digital computers, and an analog simulator was used. I was amazed that so complicated a weapon could have been fully automated. Our lecturer explained that the weapon was developed by Americans at the end of World War II and the Soviet Union had bought and reversely copied it, and 
then produced to equip the Soviet's air defence force. Automatic control and information computing were our key subjects of study.

In the 1950s, all industrial sectors like defence, aeronautics, astronautics, transportation and manufacturing processes in developed countries embarked on developing automation technology, and a large number of scientists and engineers from mathematics, physics, computers and electronics switched to cybernetics, informatics and system theory. Many countries identified these fields as priorities in their science and technology development, and the world witnessed an unprecedented boom in these three disciplines of science. The pathbreakers of this boom were the American mathematician Norbert Wiener at MIT, and the Chinese scientist Qian Xuesen 钱 学森 at Caltech.

Wiener (1894-1964) was born in Columbia, Missouri, the first child of Leo Wiener and Bertha Kahn, Jews of Polish and German origin, respectively. His farther Leo Wiener was a philology professor of Slavic languages at Harvard. A famous child prodigy, Wiener went to school at 3, graduated from college at 14, received a Ph.D. from Harvard at 18, became a tenured professor of mathematics at MIT at 25, and won the Bôcher Memorial Prize at 38. He spent the academic year 1935-1936 in China as a visiting professor at Tsinghua University in Beijing, where he was influenced by Chinese culture, as he acknowledged himself.

During World War II, Weiner was involved in developing artillery control systems. In 1948 he published The Extrapolation, Interpolation and Smoothing of Stationary Time Series, explaining what was later called the Wiener filter. In 1948, he published the Cybernetics or Control and Communication in the Animal and the Machine, which eventually led him to formulate cybernetics, attracting wide attention in the scientific community. Wiener equated the human body with machines as part of the working principle. Regarded as an offense against the dignity of man and a subversion of traditions, his cybernetics angered many Soviet philosophers, who criticized his theory as a new form of mechanistic thinking and attributed it to a reactionary pseudo-science. A more severe criticism was that cybernetics was a war tool of the imperialists ${ }^{1}$.

In 1954 Dr. Qian Xuesen, Professor in Caltech, in Pasadena, California, USA, published Engineering Cybernetics, which was immediately translated into Chinese, Russian and German. The monograph systematically expounds cybernetics' scientific and technical significance, and its far-reaching influence on various industrial sectors. Qian didn't touch up the dignity of man, it discussed only scientific and technical issues. Thus it was accepted by the scientific communities of both the eastern and the western worlds without controversies. The philosophers who were originally opposing against cybernetics quietly changed their distaste and accepted it as an "emerging science of information and control".

In September 1960, Wiener attended the $1^{\text {st }}$ World Congress of the International Federation of Automatic Control" (IFAC-1) held in Moscow and was hailed by the scientific community as a hero. Qian's work vindicated Wiener, and won Wiener's respect and love for the Chinese. The Chinese Academy of Sciences (CAS) assigned a delegation led by Wu Ruyang 武汝扬, head of the Institute of Automation of the Chinese Academy of Sciences (CASIA), to attend IFAC-1. I was invited to join the delegation and concurrently served as translator. At the congress, Wiener came to greet us in Chinese: "High tribute to the Chinese delegation!" said he, "I spent the year 1935 in China as a visiting professor at Tsinghua University. I am proud of this. I love China." In his I Am a Mathematician, Weiner said that he began to study cybernetics at Tsinghua University in 1935.

As professor Qian's admirers and friends, many participants from various countries regretted that he did not attend the congress. They knew that Qian had returned to China in October 1955 and was committed to taking charge of astronautics in his motherland. What people did not know was that the friendship and cooperation between China and Soviet Union had come to an end as Khrushchev addressed a letter to the Chinese government on July 16, 1960, announcing that Moscow would repeal 353 specialized contracts and call back all of the 1390 experts who were part of the Soviet Union's assistance for China. Due to this situation, Chinese Premier Zhou Enlai and Supreme Commander in science and technology, Marshal Nie Rongzhen 聂荣臻 (1899-1992), could not allow Qian, the chief scientist at the helm of astronautics of the country, to run a risk by attending a nongovernmental conference in Moscow. The participants could not but expressed their respect for Qian by chanting his famous lines in the preface of Engineering Cybernetics - "The justification of establishing engineering cybernetics as an engineering science lies in the possibility that looking at things in broad outline and in an organized way often leads to fruitful new avenues of approach to old problems and gives new, unexpected vistas.”

At MBTU, the length of schooling was five and a half years. The fifth year was the time to write one's gradu-

\footnotetext{
${ }^{1}$ Soviet Philosophical Dictionary and Great Soviet Encyclopedia published before 1954.
} 
ation thesis. In 1957, I was sent to Division I of the Institute of Automation of the Soviet Academy of Sciences to conduct the research for my thesis. The institute consists of two divisions-Division I for basic theories and civilian technologies, and Division II for missile and spacecraft guidance and control. I was cordially accepted by my supervisors, A. A. Feldbaum and A. Ya. Lerner, who were both well-known Soviet-Jewish scientists in cybernetics. In particular, Feldbaum was the editor-in-chief of the Russian version of Engineering Cybernetics by Qian Xuesen. Under his careful tutorage, I completed my graduation thesis Steepest Servo System Design and Experiment within six months and published it in the journal of the academy in May 1959. The inaugural success of the thesis enhanced my fondness for cybernetics and respect for Jewish scientists.

In the 1950s, young scientists in China adored most Karl Marx and Albert Einstein. Marx (1818-1883) developed the historical materialism, suggesting a logical system with predictive power amidst bewildering human history. Einstein (1879-1953) developed the theory of relativity, unifying time and space into a spatio-temporal system that removes confusions in physics and predicts a number of astronomical phenomena that were later confirmed by observations.

Marx was born into a Jewish family in Trier in Prussian Rhineland. His grandfather was a Rabbi (spiritual leader of a Jewish congregation), yet his parents led his family to convert to Christianity. Marx studied art history at the University of Bonn in 1835, studied law and philosophy at the University of Berlin in 1836, and received Ph.D. from the University of Jena in 1841. He joined the Communist League in 1847, and developed the Communist Manifesto together with Friedrich Engels in 1848. In 1849-1867, he completed Das Kapital and other works, created Marxism and became the proletariat's spiritual leader in revolution.

Einstein was born into a poor Jewish family in Ulm, in the Kingdom of Württemberg of German Empire. He studied at the University of Zürich in 1896 and received Ph.D. there in 1905. He developed the special theory of relativity in 1905 at the age of 26, and the general theory of relativity in 1916. In 1921, he was awarded the Nobel Prize in Physics for his achievements in light quanta research, becoming the greatest scientist in the $20^{\text {th }}$ century. Jewish-Dutch philosopher Baruch Spinoza (1632-1677) equated God with the natural universe in his magnum opus Tractatus Theologico Politicus (1670), therefore was said to be the "Hebrew prophet". These great scientists can be described with paraphrased biblical accolades: Marx rebuilt history of the earth with wisdom, Einstein unified heaven and time with intelligence, and Spinoza developed monism of nature in pursuit of truth.

According to historical studies (Xu Xin \& Ling Jiao, 1993), Jews originated from the Ancient Near East. Known as Hebrews, they lived in Canaan (Israel and Palestine today) around the $18^{\text {th }}$ century BCE (the Xia Dynasty in Chinese chronology). In 1750-1580 BCE, they migrated to Ancient Egypt and lived there for 400 years. Their descendants were enslaved until the Exodus led by Moses, that is commonly dated to the $13^{\text {th }}$ century BCE (the Shang Dynasty in Chinese history). Throughout two millennia, Jews had repeatedly been directly or indirectly expelled from both their original homeland and many places they inhabited. They had often been subject to discrimination, bullying, segregation, deportation and massacre by different sects and local governments for religious, cultural and consuetudinary reasons. Chinese people have always sensed sympathy and commiseration for the misery Jewish people have suffered.

On November 29, 1947, the United Nations General Assembly passed a resolution recommending Partition Plan for Palestine to be divided into a Jewish and an Arab area with Jerusalem being a U.N. administered middle ground. On May 14, 1948, David Ben-Gurion (1886-1973) declared "the establishment of a Jewish state in Eretz Israel, to be known as the State of Israel”, a state independent upon the termination of the British Mandate for Palestine, bringing the 1800-year Diaspora to an end. As of the end of the $20^{\text {th }}$ century, the Jewish people had had a worldwide population of about 14 million, including five million in Israel, accounting for 84 percent of the country's population. In the $20^{\text {th }}$ century, several million Jews migrated to America, and the US became another desirable land for Jews.

A nation could not survive thousands of years of hardships if it does not have adequate wisdom and courage. While enduring a tragic history, the Jewish people have developed a tough, confident and incisive character and a culture that highlights creative thinking, practicality and pursuit of knowledge and truth. Einstein said that, "The pursuit of knowledge for its own sake, an almost fanatical love of justice and the desire for personal independence - these are the features of the Jewish tradition which make me thank my stars that I belong to it.” Sun Yat-sen, the great leader of China's 1911 Revolution, commented that the Jewish nation has made major contributions to all areas of the world's civilization and should have an honorable position in the world (Xu Xin \& Ling Jiao, 1993). Of the 850 individuals awarded Nobel Prizes (1901-2013), at least 20\% were Jews or of Jew- 
ish descent, although Jews comprise less than $0.2 \%$ of the world's population. Jews have won a total of $41 \%$ of all the Nobel Prizes awarded in economics, 28\% in medicine, 26\% in physics and 19\% in chemistry. In the US, Jews account for only 2 percent of the population but represent one third of the Supreme Court justices and one third of the Nobel laureates (Dong Dingshan, 2014). In 2013, of the seven Nobel Prizes awarded in physics, chemistry and medicine, six were won by Jews. The Hebrew people enjoy the scripture's assignment to be God's chosen people, as mentioned in the Book of Exodus.

In 1985, when I was the Chairman of the State Science and Technology Commission (SSTC, predecessor of the Ministry of Science and Technology), we envisaged an initiative to develop agriculture by applying science and technology and mulling implementation of "Sparks Program", China's first government-led program for boosting agriculture and rural economic development based on science and technology. I heard that Israel had developed remarkable agriculture on arid land and achieved self-sufficiency in the barren, water-starved desert with the world's highest per capita supply of milk and eggs, and were exporting large quantities of fruit to Europe. In particular, I was amazed at the “dripping irrigation”, developed by Israel engineers, which could save water of 90 percent or more.

At that time China had not yet established diplomatic relations with Israel. In April 1985, I visited the US to attend the China-US Joint Commission Meeting on Science and Technology Cooperation. At the University of Texas at Austin, I met Abe Charnes, a professor of Systems Science. We had the same background and became friends. He was the son of Jewish immigrants.

I asked Charnes how to develop such agricultural technologies as stock farming and dripping irrigation in the context of reform and opening up. Here is what he said excitedly:

"Israel has fast agricultural progress and many unique advanced technologies, and China should conduct scientific and technical cooperation with Israel. Jews adore China. Over the 2000 years, Jews have undergone Diaspora and persecutions, such as Hitler's massacre of six million Jews during World War II. The only nation that has shown sympathy for Jews is China. More than 1000 years ago, Kaifeng, the capital of the Song Dynasty, sheltered multitudes of Jewish refugees. The emperor was personally concerned about the Jewish refugees, allowing them to stay in the capital city, giving them Chinese names and treating them as compatriots. Some of them passed the imperial examinations and secured official positions. In the $20^{\text {th }}$ century, tens of thousands of Jews were accepted by Harbin and lived there for half a century. Today, many Jewish scientists identify themselves as 'Harbiners'. During Hitler's massacre, 25,000 Jews fled to Shanghai and were sheltered by the city. Today, as the State of Israel has stood for almost 40 years, many Jews settled down in their homeland. Since the establishment of the PRC, Israel has been concerned about China, and tried to engage through various channels, but was not successful. Israel-China relations can start from cooperation in science and technology, so that Israel can at least make some contributions to China's agricultural development, such as through the China Sparks Program.”

On April 22, 1985, Charnes held a welcome party for us, which was attended by many famous Jewish scholars and scientists including economist Walt W. Rostow, theoretical physicist and Nobel laureate Steven Weinberg, and others. They all expressed their hope that China would explore scientific and technical cooperation with Israel.

After returning to China, I made inquiries of the Ministry of Foreign Affairs about the possibility of cooperation with Israel on agricultural science and technology. I was told that it was still not the appropriate time for China to establish diplomatic relations with Israel. In the aftermath of the fourth Middle East war (from October 6 to 25, 1973, the coalition of Arab states fought a war against Israel, until a United Nations-brokered ceasefire on October 22) that had caused a US-Soviet military confrontation, Israel was militarily victorious but diplomatically isolated. Moreover, the US and the Soviet Union were still adjusting their policies for both sides of the war. In 1988, Qian Qichen 钱其琛 took up the position of China's State Councilor and Foreign Minister. In the 1950s, he had served as deputy director of the International Student Management Office of the Chinese Embassy in the Soviet Union and for those of us who were in the Soviet Union. He was our leader for many years.

Regarding Qian as my old friend, I talked with him frankly about my expectation of establishing scientific and technical cooperation between China and Israel. He showed great sympathy for this expectation. He said that, as Yitzhak Rabin became Israeli Prime Minister, the US had resumed diplomatic relations with Egypt and Syria and Soviet-Israel relations had been normalized. China-Israel relations could start from scientific and technical cooperation. In November 1989, during his attendance to the United Nations General Assembly, For- 
eign Minister Qian reached an agreement with the Israeli Foreign Minister, under which China International Travel Service would set up an office in Tel Aviv and the Israel Academy of Sciences and Humanities would set up an office in Beijing with agricultural scientist Dr. Sha Hewei serving as the first director. Dr. Sha said in his speech that, "The establishment of the office is the first step of China-Israel cooperation for a brighter future." On January 24, 1992, China and Israel finally established official diplomatic relations.

In the 1980s, I read The Wind and Beyond (von Kármán et al., 1967) by Hungarian-American mathematician, aerospace engineer and physicist Theodore von Kármán. Kármán was tutor of Qian Xuesen at the California Institute of Technology. The book says that a physics professor sportively asked Kármán, “Qian was so talented. Do you think that he could have Jewish ancestry?” I was impressed by the over-confidence of the Jewish scholar.

In 1987, at a meeting of the Standing Committee of the State Council, when we were discussing China-Israel relations, Premier Zhao Ziyang (1919-2005) said that, "In the Northern Song Dynasty, there was a small Jewish community in Kaifeng, then the capital of China, which was sheltered and given Chinese surnames by the emperor. And my clan, who were the residents from Hua County in Anyang neighbouring to Haifeng, was just a part of the Jewish community, according to my ancestors.”

Premier Zhao kind of regretted saying this, warning the audience, "You should not spill out this message to foreigners. China has not yet established diplomatic relations with Israel, and it would be no good to say China as such a large country should have a Jewish descendant premier.” I was extremely stunned when I heard this personal revelation of the premier.

According to studies (Xu Xin \& Ling Jiao, 1993; Chen Yuan, 2009), in the Northern Song Dynasty (9601127), in Kaifeng, there was a Jewish community migrated from Mumbai, India. In its heyday, the Jewish community included 4000 people from more than 500 households with 70 surnames. They built a synagogue, chanted the Pentateuch and kept rituals as prayer, fasting, and circumcision. Four hundred years later, in the Wanli period of the Ming Dynasty (1753-1619), most of the Kaifeng Jews had scattered over the country, and only 10 - 12 clans had remained in Kaifeng. In the $15^{\text {th }}$ year of the Chongzhen period of the Ming Dynasty (1642) when the city of Kaifeng was flooded by Yellow River, 300,000 Kaifeng residents escaped out, with Hua County of Anyang District as the main place of refuge. After the disaster, only 7 with 8 surnames clans of the Kaifeng Jews (Li, Zhao, Ai, Zhang, Gao, Jin and Shi) moved back to Kaifeng, whose Chinese surnames having all been conferred on by the Song and Ming emperors.

The clan Zhao in Hua County was one of those Jews families surnamed by Emperor Zhu Di (r. 1402-1424), according to genealogy written in Chinese and Hebrew. In the fourth year of the Xianfeng period of the Qing Dynasty (1854), another flood destroyed the synagogue that had stood for more than 700 years and undergone 12 reconstructions. Since then, the synagogue has never been restored. By the second half of the Ming Dynasty, the Kaifeng Jews were diffused with local residents by intermarriage. As of the Qing Dynasty, they had been fully intermixed with the Chinese. According to studies, the Kaifeng Jews had been scattered in more than 50 counties/districts of 13 provinces/cities including Beijing, Shanghai, Nanjing, Taiyuan, Chengdu, Xining and Xi'an. By the end of the Qing Dynasty, the Kaifeng Jewish community had dissolved completely. In the $20^{\text {th }}$ century, there were over 200 households_encompassing more than 2000 people-in Kaifeng that still claimed to be descendants of Jews (Xu Xin \& Ling Jiao, 1993), but no Jewish cultural or physical features could be seen in them. In 1993, I paid a visit to the Kaifeng Jewish Community Museum, where the relics and detailed historic records are exhibited neatly.

Modern genetic theories and observations show that DNA in chromosomes is the carrier of the genetic code. Parents make their children with their genes, each contributing half. This is what is known as kinship or lineage. If parents come from different clans, kinship between one of parents and child is $1 / 2$, and that between grandparents and grandchild is $1 / 4$. So, for the gap of $N$ generation, kinship remains $(1 / 2)^{\mathrm{N}}$. Confucius (551-479) lived 2500 years ago and his $83^{\text {rd }}$-generation descendant lives at the beginning of the $21^{\text {st }}$ century. Average interval between consecutive generations is 30 years, which has been recognized by anthropologists across the world ${ }^{2}$.

For the Kaifeng Jews, since the Northern Song Dynasty, there have been more than 30 generations as of today and 13 generations from the end of the Ming Dynasty. Since the disintegration of the Kaifeng Jewish community, there have been more than five generations at least. So, even their descendants today have common Jewish ancestry, their kinship is far below $(1 / 2)^{5}=0.03$. Israel enacted the Law of Return in 1950 and the Nationality Law in 1952, which defined that a person can be identified Jewish only if his or her father or mother is Jewish.

${ }^{2}$ China Daily, a report on February 5, 2007. 
That is, a person can be recognized Jewish only if kinship is more than 0.5. So, both genetically and legally, descendants of the 7 - 8 clans of the Kaifeng Jews are not recognized as Jewish; they are just part of the Chinese people.

Genes (lineage) of a clan come down through marriage. A set of all genes, or genetic information, in any population of a society, is called a gene pool. The big gene pool of the Chinese people formed over thousands of years contains 56 legal ethnic groups now. Since the $19^{\text {th }}$ century, more ethnic groups such as British, French, Russian, German and Japanese have been added to the Chinese gene pool. Chinese historian Chen Yuan 陈垣 (1880-1971) holds that "every Chinese clan has incorporated foreign ethnicity” (Chen Yuan, 2009). Mendel's Law of genetics tells us, as long as an allele of clan exists in the gene pool, which determines a certain physical traits (e.g., blue eyes and high nose), it will never be completely dissolved but reappear repeatedly at a certain frequency. The lower the kinship is, the lower the frequency will be. Through 30 generations of intermarriages, genes of the Kaifeng Jews should have been spread in tens of millions of people and dispersed in the Big Pool of Chinese Genomes. The Kaifeng Jews' genes will appear occasionally in their descendants, while their culture has in fact disappeared thoroughly in China.

Recent studies have proven that all present-day individuals have common ancestors. In a society with a population of $\mathrm{N}$, ancients who lived before the $\mathrm{U}_{\mathrm{N}}$ generation with offsprings, $\mathrm{U}_{\mathrm{N}}=1.77 \log _{2} \mathrm{~N}$, are likely common ancestors of all present-day Chinese individuals. The probability that each person's cells contain gene copy fragment of common ancestors is 1.0 (Chang, 1999). On this basis, the ancients who lived before the Qin Dynasty (221-206 BCE) and had descendants shall be common ancestors of all present-day individuals. So, the prehistoric ancient Chinese who grew rice and millet along the Yangtze and Yellow Rivers, ancient Slavonic who herded on the Ukrainian steppe, ancient Egyptians who built pyramids, ancient Britons who made the Stonehenge and ancient Hebrews who fled from Egypt under Moses' leadership may be common direct ancestors of present-day individuals in China and elsewhere. Moreover, mounting evidences made paleoanthropologist believe that the earliest common ancestor of Homo sapiens was from Africa 100,000 - 140,000 years ago.

The knowledge of genetics and paleoanthropology gained in the $20^{\text {th }}$ century has enormously enlightened me. The saying that a Chinese person has Jewish ancestry, just like the saying that a person has Manchu or Mongolian ancestry, is nothing strange. After all, genes determine a person only in part physically, while culture and education shape a person's humanness.

\section{References}

Chang, J. T. (1999). Recent Common Ancestors of All Present-day Individuals. Applied Probability, 31, 1001-1026.

Chen Yuan 陈垣 (2009). Weida zhi zhonghua minzu (Tigang) 伟大之中华民族(提纲) [Outline of the Great Chinese Nation]. In Chen Yuan Quanji 陈垣全集 [A Collection of Works by Chen Yuan]. Hefei: Anhui Daxue Chubanshe.

Dong Dingshan 董鼎山 (2014). Zhongzu qishi 种族歧视 [Racial Prejudice]. Ta Kung Pao, B16. von Karman, T., \& Elson, L. (1967). The Wind and Beyond. New York: Little Brown \& Co.

Xu Xin 徐新, \& Ling Jiyao 凌继尧 (1993). Youtai baike quanshu 犹太百科全书 [Jewish Encyclopedia]. Shanghai: Shanghai Renmin Chubanshe. 


\section{Biography of Dr. Song Jian}

Dr. Song Jian is a distinguished scientist in the fields of control theory, system engineering and aerospace technology. He received Candidate of Science (PhD equivalent) in 1960 and Doctor of Science in 1990 from the Moscow National Technical University (MBTU). Dr. Song’s positions include the Vice Minister and Chief Engineer-Scientist of Ministry of Astronautics (1981-1984), Chairman of State Science and Technology Commission (1984-1998), State Councilor (vice premier level) of the government of the People's Republic of China (1986-1998), Chairman of National Environmental Protection Committee of State Council (1988-1998), Vice Chairman of State Leading Council of Science and Technology (1988-1998), President of Chinese Academy of Engineering (1998-2002), Vice Chairman of the $9^{\text {th }}$ National Committee of Chinese People's Political Consultative Conference (CPPCC), the national highest political advisory body (1998-2003), and First Vice Chairman of Committee on Academic Degrees of China’s State Council (1998-2003), President of China-Japan Friendship Association (1998-2011). Now he is Honorary Chairman of Presidium of Chinese Academy of Engineering and Chairman of All-China Environment Federation.

His academic titles include Member of both the Chinese Academy of Sciences and the Chinese Academy of Engineering; Honorary Professor of the Academy of Mathematics and System Sciences, Chinese Academy of Sciences; Honorary President of Harbin Institute of Technology; Foreign Member of the Russian Academy of Sciences, the US National Academy of Engineering, the Royal Swedish Academy of Engineering Sciences and the Yugoslav Academy of Engineering; Corresponding Member of the National Academy of Engineering of Mexico, the National Academy of Engineering of Argentina and Member of the International Astronautic Academy. 
Scientific Research Publishing (SCIRP) is one of the largest Open Access journal publishers. It is currently publishing more than 200 open access, online, peer-reviewed journals covering a wide range of academic disciplines. SCIRP serves the worldwide academic communities and contributes to the progress and application of science with its publication.

Other selected journals from SCIRP are listed as below. Submit your manuscript to us via either submit@scirp.org or Online Submission Portal.
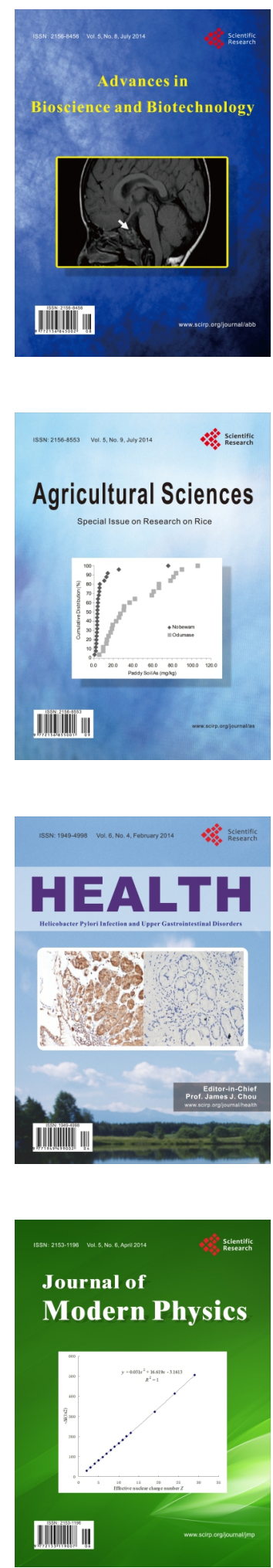
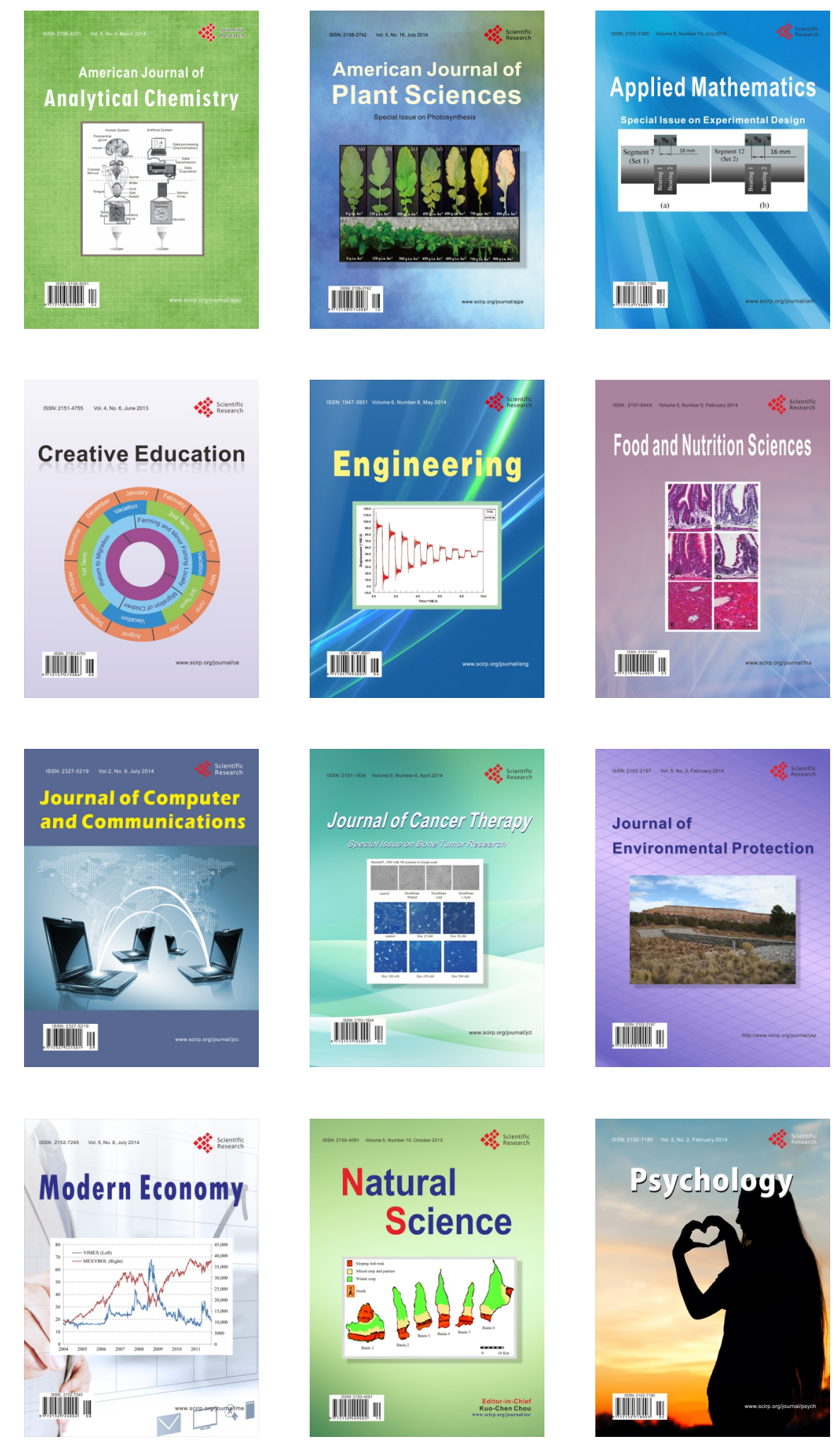